\title{
Books Received / Livres reçus 2012
}

Alsteens, Stijn and Freyda Spira. Dürer and Beyond: Central European Drawings in The Metropolitan Museum of Art, 1400-1700. With contributions by Maryan W. Ainswoth, Dirk H. Breiding, George R. Goldner, Guido Messling, Marjorie Shelley, and Joshua P. Waterman. Exhibition Catalogue. New York: The Metropolitan Museum of Art, 2012. Pp. $255+$ b/w and colour ill. ISBN 978-1-58839-451-4 (hardcover) \$65.

Ames-Lewis, Francis (ed.). Florence. Artistic Centers of the Italian Renaissance.

New York: Cambridge University Press, 2012. Pp. $424+48$ colour plates, 234 figs. ISBN 978-0-521-85162-6 (hardcover) \$175.

Ames-Lewis, Francis. Isabella and Leonardo: The Artistic Relationship Between Isabella d'Este and Leonardo da Vinci, 1500-1506. New Haven and London: Yale University Press, 2012. Pp. ix, $290+60$ colour, 60 b/w ill. ISBN 978-0300-12124-7 (hardcover) \$50.

Arena, Antonius. Ad suos compagnones ... 1531. Édition bilingue. Texte établi, traduit, annoté et commenté par Jarie-Joëlle Louison-Lassablière. Paris: Honoré Champion, 2012. 224 p. ISBN 978-2-7453-2303-3 (relié) 55€.

Atkins, Christopher D. M. The Signature Style of Frans Hals: Painting, Subjectivity, and the Market in Early Modernity. Amsterdam: Amsterdam University Press, 2012. Pp. $324+130$ ill. ISBN 978-90-89640335-3 (paperback) $\$ 49$.

Baumgarten, Jean, José Costa, Jean Patrick Guillaume et Judith Kogel (éds.). En mémoire de Sophie Kessler-Mesguich. Paris: Presses Sorbonne nouvelle, 2012. 325 p. ISBN 978-2-87854-470-8 (broché) 21€.

Blum, Paul Richard. Giordano Bruno: An Introduction. Trans. from the German by Peter Henneveld. Value Inquiry Book Series 254. Amsterdam: Rodopi, 2012. Pp. 128. ISBN 978-90-420-3555-3 (paperback) £5.

Bussels, Stijn. Spectacle, Rhetoric and Power: The Triumphal Entry of Prince Philip of Spain into Antwerp. "Ludus" Medieval and Early Renaissance Theatre and Drama 11. Amsterdam: Rodopi, 2012. Pp. $258+38$ ill. ISBN 978-90-420-3471-6 (paperback) \$77. 
Carnegie, David and Gary Taylor (eds.). The Quest for Cardenio: Shakespeare, Fletcher, Cervante, and the Lost Play. Oxford: Oxford University Press, 2012. Pp. xiv, $420+9$ ill. ISBN 978-0-19-964181-9 (hardcover) £35.

Clément, Michèle (éd.). Étienne Dolet 1509-2009. Cahiers d'Humanisme et Renaissance 98. Geneva: Droz, 2012. 518 p. ISBN 978-2-600-01542-4 (broché) $96 \$$.

Connelly, Frances S. The Grotesque in Western Art and Culture: The Image at Play. Cambridge, UK: Cambridge University Press, 2012. Pp. x, $190+62$ ill. ISBN 978-1-107-01125-0 (hardcover) \$100.95.

Datini, Margherita. Letters to Francesco Datini. Trans. Carolyn James and Antonio Pagliaro. The Other Voice in Early Modern Europe: The Toronto Series 16. Toronto: Iter Inc. / Centre for Reformation and Renaissance Studies, 2012. Pp. xiv, 431. ISBN 978-0-7727-2116-8 (paperback) \$37.

Dauvois, Nathalie. La vocation lyrique. La poétique du recueil lyrique en France à la Renaissance et le modèle des Carmina d'Horace. Paris: Éditions Classiques Garnier, 2010. 263 p. ISBN 978-2-8124-0104-6 (broché) 39.55€. Debbagi Baranova, Tatiana. À coups de libelles. Une culture politique au temps des guerres de religion (1562-1598). Préface de Denis Crouzet. Cahiers d'Humanisme et Renaissance 104. Genève: Librairie Droz, 2012. 502 p. ISBN 978-2-600-01577-6 (broché) 69.60\$.

del Nacimiento, Cecilia. Journeys of a Mystic Soul in Poetry and Prose. Intro. and prose trans. by Kevin Donnelly. Poetry trans. by Sandra Sider. The Other Voice in Early Modern Europe: The Toronto Series 18. Toronto: Iter Inc. / Centre for Reformation and Renaissance Studies, 2012. Pp. xi, 548. ISBN 978-0-7727-2118-1 (paperback) \$37.

DeSilva, Jennifer Mara (ed.). Episcopal Reform and Politics in Early Modern Europe. Early Modern Studies 10. Kirksville, MO: Truman State University Press, 2012. Pp. xiv, 226. ISBN 978-1-61248-072-5 (paperback) \$56.25.

Deutsch, Helen and Mary Terrall (eds.). Vital Matters: Eighteenth-Century Views of Conception, Life, and Death. Toronto: University of Toronto Press, 2012. Pp. x, 333 + 18 ill. ISBN 978-1-4426-4258-4 (hardback) \$70.

D’Evelyn, Margaret Muther. Venice \& Vitruvius: Reading Venice with Daniele Barbaro and Andrea Palladio. Pp. $504+142$ b/w, 1 colour ill. ISBN 978-0300-17451-9 (hardbound) \$65.

Douglas, Margaret et al. The Devonshire Manuscript: A Women's Book of Courtly Poetry. Ed. and intro. by Elizabeth Heale. The Other Voice in Early 
Modern Europe: The Toronto Series 19. Toronto: Iter Inc. / Centre for Reformation and Renaissance Studies, 2012. Pp. 277 ISBN 978-0-77272128-0 (paperback) \$24.50.

Dunn-Lardeau, Brenda (éd.). Humanistes italiens et imprimés de l'Italie de la Renaissance dans le Collections de l'UQAM. Montréal: Figura, Centre de recherche sur le texte et l'imaginaire / Presses de l'Université du Québec, 2012. 330 p. ISBN 978-2-923907-25-3 (broché) 20\$.

Duru, Audrey. Essais de soi. Poésie spirituelle et rapport à soi, entre Montaigne et Descartes. Travaux d'Humanisme et Renaissance 56. Genève: Droz, 2012. 509 p. ISBN 978-2-600-01572-1 (broché) 146.90\$.

Emison, Patricia. The Italian Renaissance and Cultural Memory. New York: Cambridge University Press, 2012. Pp. $238+12$ colour plates and 59 figures. ISBN 978-1-107-00526-6 (hardcover) \$90.

Ebert-Schifferer, Sybille. Caravaggio: The Artist and His Work. Los Angeles: The J. Paul Getty Museum, 2012. Pp. 319 + 187 ill. ISBN 978-1-60606-095-7 (hardcover) \$59.95.

Eisenbichler, Konrad. The Sword and the Pen: Women, Politics, and Poetry in Sixteenth-Century Siena. Notre Dame, IN: University of Notre Dame Press, 2012. Pp. xi, 371. ISBN 978-0-268-02776-6 (paperback) \$32.

Erasmus, Desiderius and Martin Luther. The Battle Over Free Will. Ed. with notes by Clarence $\mathrm{H}$. Miller, trans. by Clarence $\mathrm{H}$. Miller and Peter Macardle. Intro. by James D. Tracy. Indianapolis / Cambridge: Hackett Publishing Company, Inc., 2012. Pp. xxv, 355. ISBN 978-1060384-547-2 (paperback) \$16.95.

Erasmus, Desiderius. The Correspondence of Erasmus: Letters 2082 to 2203. Ed. James M. Estes and trans. Alexander Dalzell. Collected Works of Erasmus 15. Pp. 403. ISBN 978-1-4426-4203-4 (hardcover) \$175.

Graves-Monroe, Amy. Post tenebras lex. Preuves et propagande dans l'historiographie engagée de Simon Goulart (1543-1628). Travaux d'Humanisme et Renaissance, 499. Geneva: Droz, 2012. 344 p. ISBN 9782-600-01457-1 (relié) 102\$.

Gregory, Brad S. The Unintended Reformation: How a Religious Revolution Secularized Society. Cambridge, MA: The Belknap Press of Harvard University Press, 2012. Pp. 574. ISBN 978-0-674-04563-7 (hardcover) $\$ 39.95$. 
Gregory, Sharon and Sally Anne Hickson (eds.). Inganno-The Art of Deception: Imitation, Reception, and Deceit in Early Modern Art. Visual Culture in Early Modernity. Farnham, UK, and Burlington, VT: Ashgate, 2012. Pp. xi, $204+21$ ill. ISBN 978-1-4094-3149-7 (hardcover) \$104.95.

Harbison, Craig. Jan van Eyck: The Play of Realism. Second updated and expanded edition. London: Reaktion Books, 2012. Pp. $317+139$ ill. ISBN 978-1-86189-820-3 (paperback) \$29.95.

Helfer, Rebeca. Spenser's Ruins and the Art of Recollection. Toronto: University of Toronto Press, 2012. Pp. xiii, 391. ISBN 978-0-8020-9067-6 (hardcover) $\$ 85$.

Helgeson, James. The Lying Mirror:The First-Person Stance and Sixteenth-Century Writing. Les Seuils de la Modernité 14. Geneva: Droz, 2012. Pp. 334. ISBN 978-2-600-01545-5 (paperback) \$67.20.

Howard, Peter. Creating Magnificence in Renaissance Florence. Essays and Studies 29. Toronto: Centre for Reformation and Renaissance Studies, 2012. Pp. 173. ISBN 978-0-7727-2126-6 (paperback) \$19.

Ianziti, Gary. Writing History in Renaissance Italy: Leonardo Bruni and the Uses of the Past. Cambridge, MA: Harvard University Press, 2012. Pp. 418. ISBN 978-0-647-06152-1 (hardcover) \$49.95.

Kavaler, Ethan Matt. Renaissance Gothic: Architecture and the Arts in Northern Europe 1470-1540. New Haven and London: Yale University Press, 2012. Pp. $344+80$ colour, 210 b/w ill. ISBN 978-0-300-16792-4 (hardcover) \$75. King'oo, Clare Costley. Miserere Mei: The Penitential Psalms in Late Medieval and Early Modern England. Notre Dame, IN: University of Notre Dame Press, 2012. Pp. xix, 283. ISBN 978-0-268-03324-8 (paperback) \$38.

Kusukawa, Sachiko. Picturing the Book of Nature: Image, Text, and Argument in Sixteenth-Century Human Anatomy and Medical Botany. Chicago: The University of Chicago Press, 2012. Pp. xvii, $331+120$ ill. ISBN 978-0-22646529-6 (hardcover) \$45.

La Charité, Claude et Roxanne Roy (éds.). Femmes, rhétorique et éloquence sous l'Ancien Régime. L'école du genre. Saint-Étienne: Publications de l'Université de Saint-Étienne, 2012. 419 p. ISBN 978-2-86272-608-3 (broché) $35 €$.

Laurenza, Domenico. Art and Anatomy in Renaissance Italy: Images from a Scientific Revolution. New York: The Metropolitan Museum of Art; 
distributed by New Haven: Yale University Press, 2012. Pp. $48+68$ colour, 4 b/w ill. ISBN 978-1-58839-456-9 (paperback) \$14.95.

Lawrence, Sean. Forgiving the Gift: The Philosophy of Generosity in Shakespeare and Marlowe. Pittsburgh, PA: Duquesne University Press, 2012. Pp. xxiii, 244. ISBN 978-0-8207-0448-7 (hardcover) \$58.

Levy, Ian Christopher. Holy Scripture and the Quest for Authority at the End of the Middle Ages. Reading the Scriptures. Notre Dame, IN: University of Notre Dame Press, 2012. Pp. xvi, 320. ISBN 978-0-268-03414-6 (paperback) $\$ 38$.

Manetti, Giannozzo. Historia pistoriensis. Ed. Stefano U. Baldassarri and Benedetta Aldi. Florence: SISMEL / Edizioni del Galluzzo, 2011. Pp. xv, 270. ISBN 978-88-8450-442-5 (hardcover) €54.

Marinella, Lucrezia. Exhortations to Women and to Others if They Please. Ed. and trans. by Laura Benedetti. Toronto: Iter Inc. / Centre for Reformation and Renaissance Studies, 2012. Pp. 220. ISBN 978-0-7727-2114-3 (paperback) $\$ 21.50$.

Marlowe, Christopher. The Jew of Malta. Ed. Mathew R. Martin. Peterborough, ON: Broadview Editions, 2012. Pp. 289. ISBN 978-1-55481-068-0 (paperback) $\$ 18.95$.

Montaigne, Michel de. Selected Essays: With La Boétie’s Discourse on Voluntary Servitude. Trans. James B. Atkinson and David Sices. Intro. and notes by James B. Atkinson. Indianapolis, IN: Hackett Publishing Company, 2011. Pp. 410. ISBN 978-1-60384-595-3 (paperback) \$12.95.

Murray, Jacqueline (ed.). Marriage in Premodern Europe: Italy and Beyond. Essays and Studies 27. Toronto: Centre for Reformation and Renaissance Studies, 2012. Pp. $393+12$ b/w and colour ill. ISBN 978-0-7727-2122-8 (paperback) \$32.

Piéjus, Marie-Françoise, Michel Plaisance, and Matteo Residori (éds.). Alessandro Piccolomini (1508-1579). Un siennois à la croisée des genres et des savoirs. Actes du Colloque International (Paris, 23-25 septembre 2010). Centre Interuniversitaire de Recherche sur la Renaissance Italienne 31. Paris: Université Sorbonne Nouvelle Paris 3, 2011. 295 p. ISBN 978-2-900478-31-8 (broché) 30€.

Prendergast, Maria Teresa Michaela. Railing, Reviling, and Invective in English Literary Culture, 1588-1617: The Anti-Poetics of Theater and Print. Material Readings in Early Modern Culture Farnham, UK and Burlington, 
VT: Ashgate, 2012. Pp. xii, 246 + 4 ill. ISBN 978-1-4094-3809-0 (hardcover) \$99.95.

Raiswell, Richard and Peter Dendle (eds.). The Devil in Society in Premodern Europe. Essays and Studies 28. Toronto: Centre for Reformation and Renaissance Studies, 2012. Pp. $568+20$ ill. ISBN 978-0-7727-2124-2 (paperback) \$37.

Rijser, David. Raphael's Poetics: Art and Poetry in High Renaissance Rome. Amsterdam: Amsterdam University Press, 2012. Pp. xxvii, $475+8$ figs., 18 plates. ISBN 978-90-8964-342-1 (paperback) \$47.50.

Rothman, E. Natalie. Brokering Empire: Trans-Imperial Subjects Between Venice and Istanbul. Ithaca, NY: Cornell University Press, 2012. Pp. xx, $350+9$ ill. ISBN 978-0-8014-4907-9 (hardcover) \$45.

Smith, Nicole D. Sartorial Strategies: Outfitting Aristocrats and Fashioning Conduct in Late Medieval Literature. Notre Dame, IN: University of Notre Dame Press, 2012. Pp. xiii, 281 + 5 figs. ISBN 978-0-268-04137-3 (paperback) $\$ 35$.

Soergel, Philip M. Miracles of the Protestant Reformation: The Evangelical Wonder Book in Reformation Germany. Oxford Studies in Historical Theology. New York: Oxford University Press, 2012. Pp. $234+10$ b/w ill. ISBN 978-0-19-984466-1 (hardcover) £40.

Staley, Lynn. The Island Garden: England's Language of Nation from Gildas to Marvell. Notre Dame, IN: University of Notre Dame Press, 2012. Pp. x, 345. ISBN 978-0-268-04140-3 (paperback) \$39.

Stawarz-Luginbühl, Ruth. Un théâtre de l'épreuve. Tragédies huguenotes en marge des guerres de religion en France 1550-1573. Travaux d'Humanisme et Renaissance 55. Genève: Librairie Droz, 2012. 696 p. ISBN 978-2-600-01578-3 (relié) 114\$.

The English Bible, The King James Version: The Old Testament, Vol. 1. Ed. Herbert Marks. A Norton Critical Edition. New York and London: W. W. Norton \& Company, 2012. Pp. xxviii, 2274 + 5 maps. ISBN 978-0-39392745-0 (paperback) \$22.50.

The English Bible, The King James Version: The New Testament and the Apocrypha, Vol. 2. Ed. Gerald Hammond and Austin Busch. A Norton Critical Edition. New York and London: W. W. Norton \& Company, 2012. Pp. xxxii, $1510+5$ maps. ISBN 978-0-393-97507-9 (paperback) \$22.50. 
Walton, Michael T. Genesis and the Chemical Philosophy: True Christian Science in the Sixteenth and Seventeenth Centuries. AMS Studies in the Renaissance 45. New York: AMS Press, 2011. Pp. xiii, 172. ISBN 978-0-404-62345-6 (hardback) \$92.50.

Woollett, Anne T., Yvonne Szafran, and Alan Phenix. Drama and Devotion: Heemskerck's Ecce Homo Altarpiece from Warsaw. Los Angeles: J. Paul Getty Museum / Getty Publications, 2012. Pp. 92 + ill. ISBN 978-1-60606112-1 (paperback) \$25. 
